\title{
LETTER
}

\section{K-Ar biotite and fission-track zircon ages of the Nisatai Dacite, Iwate Prefecture, Japan: A candidate for Tertiary age standard}

\author{
TAKAHIRO TAGAMI ${ }^{1}$, KOZO UTO ${ }^{2}$, TAKAAKI MATSUDA ${ }^{3}$, \\ NORIKO HASEBE ${ }^{1}$ and AKIKAZU MATSUMOTO ${ }^{2}$ \\ ${ }^{1}$ Department of Geology and Mineralogy, Faculty of Science, Kyoto University, Kyoto 606, Japan \\ ${ }^{2}$ Geological Survey of Japan, Higashi 1-1-3, Tsukuba 305, Japan \\ ${ }^{3}$ Department of Geology, Faculty of Science, Himeji Institute of Technology, Himeji 671-22, Japan
}

(Received March 1, 1994; Accepted January 12, 1995)

\begin{abstract}
$\mathrm{K}-\mathrm{Ar}$ biotite and fission-track (FT) zircon ages were determined on the Nisatai Dacite (ND), Iwate Prefecture, Japan, to assess its suitability for a geologic age standard. The concentration of potassium and argon isotope ratios were determined on a biotite sample twice and three times, respectively, and yielded reproducible results within analytical errors. A K-Ar age was given as $21.0 \pm 0.3$ ( 2 sigma) Ma. FT zircon ages were determined on two samples from different localities as $21.8 \pm 1.4(2 \mathrm{sigma})$ and $23.9 \pm 1.4 \mathrm{Ma}$. The K-Ar age was obtained from an outcrop adjacent to that for the former FT age, with a good agreement between the two methods. The concordance in age, in conjunction with previous zircon FT length data, suggests a potential applicability of the ND to both the K-Ar and FT system calibration in Cenozoic time.
\end{abstract}

\section{INTRODUCTION}

Analysis of age standards provides an important baseline for reliable interlaboratory comparison of radiometric age data (e.g., Alexander and Davis, 1974; Hurford and Green, 1983). In particular, age standards are routinely employed for the ${ }^{40} \mathrm{Ar} /{ }^{39} \mathrm{Ar}$ and fission-track (FT) methods, both of which involve neutron irradiation processes in a nuclear reactor and accordingly require precise assessment of neutron dose. Repeated measurements of a set of standards varying in age and other characteristics also provide various information about the reproducibility and accuracy of age determination at individual laboratories. Such a procedure was formally commended to standardize the FT system calibration by the I.U.G.S. Subcommission on Geochronology (Hurford, 1990).

Several age standards have been successfully used for the system calibration as well as for the interlaboratory comparison of radiometric ages: e.g., P207 muscovite (Lanphere and Darlymple, 1967); Bern 4B biotite and 4M muscovite (Flish, 1982); Fish Canyon Tuff biotite, sanidine, apatite and zircon (Naeser et al., 1981; Cebula et al., 1986); and MMhb-1 hornblende (Samson and Alexander, 1987). As a working standard for $\mathrm{Ar}$ analysis in Japan, the Sori granodiorite biotite of $\sim 91 \mathrm{Ma}$ was collected from the geochemical standard JG1 locality (Ando et al., 1975) and has been widely used (e.g., Uchiumi and Shibata, 1980; Matsumoto et al., 1989). As was discussed in detail elsewhere (Uto et al., 1994), the precise age determination of Neogene to Quaternary rocks is highly important for reconstructing various geologic processes at active continental margins, particularly volcanic and tectonic histories. In this regard, it is strongly needed to establish a set of $\mathrm{K}-\mathrm{Ar}$ and FT age standards from such young rocks by detailed intercalibration between the two techniques. The aim of this study is to characterize a 
candidate for such standards, i.e., the Nisatai Dacite (ND), which contains a sufficient amount of fresh, euhedral biotite and zircon crystals suitable for K-Ar and FT analyses, respectively. Note that the suitability of the ND to a FT zircon standard has also been suggested through track length analyses (Matsuda, 1992; Hasebe et al., 1994; Yamada et al., 1995).

\section{Sample Preparation and ANalytical Procedures}

The Nisatai Dacite (ND) is a dacitic volcanic formation that occurs in and around Ninohe city, Iwate prefecture, Japan. The ND consists primarily of dacitic welded tuffs and occupies the lowest horizon of the Miocene Ninohe Group, overlying the pre-Cenozoic basements (Samata, 1976; see also Otuka, 1934; Chinzei, 1966). A K-Ar age of $21.8 \mathrm{Ma}$ was previously reported on the ND (Kimura, 1986), although no detailed information was given about the sampling localities and analytical procedures therein. The rock samples analysed in this study were collected from dacitic welded tuff outcrops, correlative to the upper part of the ND (Samata, 1976). The sampling sites (NST, $40^{\circ} 15.7^{\prime} \mathrm{N}, 141^{\circ} 20.9^{\prime} \mathrm{E}$; NS-630, $40^{\circ} 17.3^{\prime}$ $\mathrm{N}, 141^{\circ} 20.0^{\prime} \mathrm{E}$; NS-704B, $40^{\circ} 15.7^{\prime} \mathrm{N}, 141^{\circ} 20.8^{\prime}$ E: see Tables 1 and 2) are located to the west of the Mt. Oritsume, where the thickness of the formation reaches the maximum at around $200 \mathrm{~m}$. The rock sample NST for K-Ar dating was collected from a fresh, large outcrop adjacent to NS704B, one of the rock samples for which FT ages were measured prior to the sampling for $\mathrm{K}-\mathrm{Ar}$ dating.

\section{$K$-Ar dating}

The NST sample contains a sufficient amount of fresh biotites suitable for $\mathrm{K}-\mathrm{Ar}$ dating, which were separated by the following procedures. After crushing with a rock trimmer, a Jaw-crusher and a disk mill grinder, the sample was washed with water to remove fine rock powders. Subsequently, biotites were concentrated with bromoform heavy liquid solution, Frantz ferrofilter and Sumitomo 
Table 2. Analytical results of fission-track dating on zircon samples from the Nisatai Dacite

\begin{tabular}{|c|c|c|c|c|c|c|c|}
\hline Sample name & $n$ & $\begin{array}{c}\rho_{\mathrm{s}}\left(N_{\mathrm{s}}\right) \\
\left(\times 10^{6} \mathrm{~cm}^{-2}\right)\end{array}$ & $\begin{array}{c}\rho_{\mathrm{i}}\left(N_{\mathrm{i}}\right) \\
\left(\times 10^{6} \mathrm{~cm}^{-2}\right)\end{array}$ & $\begin{array}{c}\rho_{\mathrm{d}}\left(N_{\mathrm{d}}\right) \\
\left(\times 10^{5} \mathrm{~cm}^{-2}\right)\end{array}$ & $\begin{array}{c}T \\
(\mathrm{Ma})\end{array}$ & $\begin{array}{c}P\left(\chi^{2}\right) \\
(\%)\end{array}$ & $r$ \\
\hline NS-630 & 17 & 3.21 (2469) & $4.13(3175)$ & $1.67(7054)$ & $23.9 \pm 1.4$ & 5 & 0.961 \\
\hline NS-704B & 11 & $2.94(2133)$ & $3.93(2850)$ & $1.58(6690)$ & $21.8 \pm 1.4$ & 25 & 0.977 \\
\hline & & & & weighted mean & $22.8 \pm 1.0$ & & \\
\hline
\end{tabular}

$n=$ number of crystals counted, $\rho_{s}=$ spontaneous track density of a sample, $N_{s}=$ number of tracks counted to determine $\rho_{s}, \rho_{i}$ = induced track density of a sample measured in a muscovite external detector, $N_{i}=$ number of tracks counted to determine $\rho_{i}$, $\rho_{d}=$ induced track density of glass dosimeter NBS-SRM612 measured in a muscovite external detector, $N_{d}=$ number of tracks counted to determine $\rho_{d}, T=$ fission-track age with \pm 2 sigma Poisson error, $P\left(\chi^{2}\right)=$ probability of obtaining the observed value of Galbraith's (1981) $\chi^{2}$ parameter, for $N$ degrees of freedom, where $N=$ (number of crystals) -1 , quoted to the nearest $5 \%$ or $10 \%, r=$ correlation coefficient between $\rho_{s}$ and $\rho_{i}$ measured for individual crystals.

Samples were analysed by T. Matsuda.

TA-Neomax magnet, and then completely separated by a Frantz isodynamic magnetic separator and tapping technique. Finally, the biotite separates were sieved to serve the $42-60$ mesh size grains for potassium and argon measurements.

The concentration of $\mathrm{K}$ in biotite was determined by the flame emission spectrometry using the Kotaki FIP-3D system, in which lithium internal standard and peak integration were adopted. The laboratory procedure for $\mathrm{K}$ analysis was described in detail elsewhere (Matsumoto, 1989). The isotope analyses of Ar were performed with a VG Isotopes $1200 \mathrm{C}$ mass spectrometer. We employed the peak height comparison method (Takaoka et al., 1989), wherein the concentration of ${ }^{40} \mathrm{Ar}$ in sample is obtained by comparing peak intensities with the known amount of air standard. The laboratory procedures of $\mathrm{Ar}$ analysis adopted in this study were documented by Matsumoto et al. (1989).

Ages were calculated using the following constants and atmospheric initial ${ }^{40} \mathrm{Ar} /{ }^{36} \mathrm{Ar}$ ratio (i.e., 295.5): $\lambda_{\beta}=4.962 \times 10^{-10} \mathrm{y}^{-1}, \lambda_{e}=0.581 \times 10^{-10}$ $\mathrm{y}^{-1},{ }^{40} \mathrm{~K} / \mathrm{K}=0.01167 \%$ (Steiger and Jager, 1977).

\section{Fission-track dating}

A sufficient amount of euhedral zircons suitable for FT analysis were separated from the two rock samples of the ND, using the conventional heavy liquid and magnetic separation techniques. FT ages were determined by the external detector method (e.g., Naeser, 1976), as will be briefly described below. After mounting onto a PFA teflon sheet, zircon crystals were ground then polished to expose internal surfaces. The mount was then etched with $\mathrm{KOH}: \mathrm{NaOH}$ eutectic etchant (Gleadow et al., 1976) at $225^{\circ} \mathrm{C}$ for $\sim 20 \mathrm{hr}$, until spontaneous tracks were optimally revealed. An Indian Bihar muscovite sheet was firmly attached on the mount, and the samples were packed for irradiation between two NBS-SRM612 glass dosimeters. The neutron irradiation was performed for $30 \mathrm{~min}$ at the Irradiation Pit facility of the Musashi Institute of Technology reactor. In this facility, a nominal thermal neutron flux and a $\mathrm{Cd}$ ratio for $\mathrm{Au}$ monitor are $\sim 8 \times 10^{11} \mathrm{~cm}^{-2} \mathrm{~s}^{-1}$ and 13-15, respectively (T. Honda, pers. commun., 1986). The external detector muscovite was etched with $46 \% \mathrm{HF}$ at $20^{\circ} \mathrm{C}$ for $20 \mathrm{~min}$ to reveal induced tracks optimally. Tracks were counted throughout under a Nikon Biophot optical microscope with $100 \times$ dry objective and $10 \times$ eyepieces. FT ages were calibrated by the zeta calibration method (Hurford and Green, 1983) using a zeta factor of $365.8 \pm 7.0$ (2 sigma).

\section{RESUltS AND DISCUSSION}

Table 1 presents the analytical results of $\mathrm{K}-\mathrm{Ar}$ dating on the NST biotite sample. The potassium content and argon isotope ratios were determined twice and three times, respectively, on individual 
aliquots of the sample. The repeated determinations of potassium show a good agreement, giving an average of $8.38 \pm 0.08 \%$ (errors for all data are consistently given at \pm 2 sigma hereafter) as $\mathrm{K}_{2} \mathrm{O}$. Meanwhile, the argon isotope ratios are also reproducible at $\sim 5.7 \times 10^{-6} \mathrm{ml} \mathrm{STP} / \mathrm{g}$. A weighted mean age for the NST biotite sample is thus given as $21.0 \pm 0.3 \mathrm{Ma}$.

FT zircon ages were determined as $23.9 \pm 1.4$ and $21.8 \pm 1.4 \mathrm{Ma}$ on samples NS-630 and NS$704 \mathrm{~B}$, respectively, showing a reasonable concordance with each other (Table 2). The latter FT age also shows a good agreement with the $\mathrm{K}-\mathrm{Ar}$ age, both of which were obtained from outcrops adjacent to each other (see their sampling sites and explanations). The concordant results between the two methods suggest a potential applicability of the ND to both the K-Ar and FT system calibration. In addition to these age data, mean horizontal-confined-track (HCT) lengths are concordant between spontaneous and induced tracks in the NST zircon, and this confirms both the rapid cooling of the rock subsequent to its formation and the absence of effective thermal overprints (Yamada et al., 1995). It is also remarked that the mean induced HCT length of NST zircon is similar to those of other natural zircons of different geneses (Hasebe et al., 1994). These lines of evidence further support that the ND is a potential candidate for a geologic age standard.

With respect to stratigraphic implication, the present results accord with the regional existence of unconformity at about $19 \mathrm{Ma}$, covering nearly the whole of the Tohoku district (Kimura, 1986). In the Ninohe city area, the Yotsuyaku formation that includes the Kadonosawa fauna unconformably overlies the Nisatai formation (e.g., Otuka, 1934; Chinzei, 1966; Samata, 1976). The Kadonosawa fauna is an important age marker indicating the occurrence of $\sim 15.5$ Ma (Kimura, 1986; see also Samata, 1976). The Keiseitoge andesite, which has an interfingering relationship with the middle part of the Yotsuyaku formation, yields a K-Ar age of 15.9 Ma (Kimura, 1986). Hence the stratigraphic discontinuity at about 16$20 \mathrm{Ma}$ is confirmed between the Nisatai dacite and the Keiseitoge andesite, which probably represents the overall Yotsuyaku formation in age.

Acknowledgments - We wish to thank Dr. Teruyuki Honda for his help in neutron irradiation at the Musashi Institute of Technology reactor; Messrs. Hisatoshi Ito and Ryuji Yamada for their help in the rock sampling and mineral separation.

\section{REFERENCES}

Alexander, E. C., Jr. and Davis, P. K. (1974) ${ }^{40} \mathrm{Ar}-{ }^{39} \mathrm{Ar}$ ages and trace element contents of Apollo 14 breccias; an interlaboratory cross-calibration of ${ }^{40} \mathrm{Ar}-{ }^{39} \mathrm{Ar}$ standards. Geochim. Cosmochim. Acta 38, 911-928.

Ando, A., Kurasawa, H. and Uchiumi, S. (1975) Evaluation of $\mathrm{Rb}, \mathrm{Sr}, \mathrm{K}$ and $\mathrm{Na}$ contents of the GSJ JG-1 granodiorite and JB-1 basalt. Bull. Geol. Surv. Jpn. 26, 335-348.

Cebula, G. T., Kunk, M. J., Mehnert, H. H., Naeser, C. W., Obradovich, J. D. and Sutter, J. F. (1986) The Fish Canyon Tuff, a potential standard for the ${ }^{40} \mathrm{Ar}-{ }^{39} \mathrm{Ar}$ and fission-track dating methods. 6th Int. Conf. Geochr. Cosmochr. Isot. Geol. Abstr. 139.

Chinzei, K. (1966) Younger Tertiary geology of the Mabechi River valley, Northeast Honsyu, Japan. $J$. Fac. Sci. Univ. Tokyo 16, 161-208.

Flish, M. (1982) Potassium-argon analysis. Numerical Dating of Stratigraphy (Odin, G. S., ed.), 151-158, Wiley, Chichester.

Galbraith, R. F. (1981) On statistical models for fission track counts. Math. Geol. 13, 471-488.

Gleadow, A. J. W., Hurford, A. J. and Quaife, R. D. (1976) Fission track dating of zircon: improved etching techniques. Earth Planet. Sci. Lett. 33, 273276.

Hasebe, N., Tagami, T. and Nishimura, S. (1994) Towards zircon fission-track thermochronology: Reference framework for confined track length measurements. Chem. Geol. (Isot. Geosci. Sec.) 112, 169178.

Hurford, A. J. (1990) Standardization of fission track dating calibration: Recommendation by the Fission Track Working Group of the I.U.G.S. Subcommission on Geochronology. Chem. Geol. (Isot. Geosci. Sect.) 80, 171-178.

Hurford, A. J. and Green, P. F. (1983) The zeta age calibration of fission-track dating. Isotope Geosci. 1, 285-317.

Kimura, K. (1986) Radiometric dating stratigraphy of Tertiary system in Tohoku District. Gekkan Chikyu (Earth monthly) 8, 370-375.

Krummenacher, D. (1970) Isotopic composition of ar- 
gon in modern surface volcanic rocks. Earth Planet. Sci. Lett. 8, 109-117.

Lanphere, M. A. and Dalrymple, G. B. (1967) K-Ar and $\mathrm{Rb}-\mathrm{Sr}$ measurements on P-207, the U.S.G.S. interlaboratory standard muscovite. Geochim. Cosmochim. Acta 31, 1091-1094.

Matsuda, T. (1992) Comparison of fission-track thermal stability between external and internal surfaces of zircon. 7th Int. Workshop Fission-Track Thermochronology Abstr. 62.

Matsumoto, A. (1989) Improvement for determination of potassium in K-Ar dating. Bull. Geol. Surv. Jpn. 40, 65-70.

Matsumoto, A., Uto, K. and Shibata, K. (1989) K-Ar dating by peak comparison method-New technique applicable to rocks younger than 0.5 Ma. Bull. Geol. Surv. Jpn. 40, 565-579.

Naeser, C. W. (1976) Fission track dating. U.S. Geol. Surv. Open File Rep. 76-190, 1-65.

Naeser, C. W., Zimmermann, R. A. and Cebula, G. T. (1981) Fission-track dating of apatite and zircon: an interlaboratory comparison. Nucl. Tracks 5, 65-72.

Otuka, Y. (1934) Tertiary structures of the Northwestern end of the Kitakami mountainland, Iwate Prefecture, Japan. Bull. Earthq. Res. Inst. 12, 566-638.

Samata, T. (1976) Planktonic foraminifer stratigraphy of Neogene strata in Mabuchigawa river area, northern margin of the Kitakami mountains. J. Geol. Soc. Jpn. 82, 783-793.

Samson, S. D. and Alexander, E. C., Jr. (1987) Calibration of the interlaboratory ${ }^{40} \mathrm{Ar}-{ }^{39} \mathrm{Ar}$ dating standard, MMhb-1. Chem. Geol. (Isot. Geosci. Sec.) 66, 27-34.

Steiger, R. H. and Jager, E. (1977) Subcommission on geochronology: Convention on the use of decay constants in geo- and cosmochronology. Earth Planet. Sci. Lett. 36, 359-362.

Takaoka, N., Konno, K., Oba, Y. and Konda, T. (1989) $\mathrm{K}$-Ar dating of lavas from Zao Volcano, Northeastern Japan. J. Geol. Soc. Jpn. 95, 157-170.

Uchiumi, S. and Shibata, K. (1980) Errors in K-Ar age determination. Bull. Geol. Surv. Jpn. 31, 267-273.

Uto, K., Tagami, T. and Uchiumi, S. (1994) K-Ar and fission-track dating on volcanic rocks of Pliocene Teragi Group from eastern San'in region, Southwest Japan. J. Geol. Soc. Jpn. 100, 787-798.

Yamada, R., Tagami, T. and Nishimura, S. (1995) Confined fission-track length measurement of zircon: assessment of factors affecting the paleotemperature estimate. Chem. Geol. (Isot. Geosci. Sec.) 119, 293306. 